\title{
Prevalence of hypertension in the urban and rural Zulu
}

\author{
Y K SEEDAT, ${ }^{1}$ M A SEEDAT, ${ }^{1}$ AND D B T HACKLAND ${ }^{2}$ \\ From the Department of Medicine, ${ }^{1}$ University of Natal, Durban, Republic of South Africa, and Bethesda \\ Hospital, ${ }^{2}$ Ubombo, Kwa Zulu
}

SUMMARY In a house-to-house study of 994 urban Zulus the prevalence of hypertension according to WHO criteria was $25 \%$ ( $23 \%$ men, $27 \%$ women). In a rural Zulu study of 987 the prevalence age corrected to the urban distribution was $9.4 \%$ (8.7\% men, $10 \%$ women). Thus there was a pronounced difference between the prevalence of hypertension in the urban and rural Zulu $(p<0.0005)$. There was an earlier onset of hypertension in the urban compared with the rural Zulu. Contrasting biosocial factors in the urban and rural Zulu could explain the differences in prevalence. Our study suggests that hypertension is not a major health problem in rural Zulus. Large-scale case finding and intervention programmes should be confined to the urban black population of South Africa.

Hypertension is extremely common in the urbanised black population in hospital in South Africa. ${ }^{1-4}$ After violence, the second most common cause of death in Johannesburg is hypertension and its complications. ${ }^{5}$ We report the prevalence of hypertension in Durban, a city with a population in 1976 of 500000 Indians, 370000 Zulus, and 216000 whites. $^{\circ}$

A rural study was done in Ubombo in the north-eastern part of Kwa Zulu. The central point in this area was Bethesda Hospital, high in the Ubombo range of mountains. The population of this area is 70000 and the people live on the mountains and the vast Makhatini flats. Most are illiterate and their mode of living is simple.

\section{Subjects and methods}

One thousand subjects were chosen from each of the groups for study. Because of difference in the life style between the urban and rural Zulu it was necessary to adopt a different approach in interviewing a subject. This technique could produce biases that affect rural people differently from urban ones. The urban residential areas were divided into blocks. The street at the end of each block was chosen and one in three dwellings was visited. The adult answering the door was selected as subject. In the hostels (men only) one person in every third room was selected for the study. All subjects were urbanised-that is, they had lived in the city for at least five years. Accommodation for the urban black consisted mainly of subeconomic houses (two bedrooms, lounge, and kitchen), some of which had been expanded at the tenant's cost, or hostels with an average of five men in each room.

The rural population has been affected by migratory labour, and many of the men had spent time away from the rural area; thus fewer men were interviewed than women. The family unit in most cases consisted of two to three huts. During a visit to the kraal the first person interviewed was usually a man, if present. The purpose of the visit was explained carefully, and other members were chosen on the criterion of the person who showed the greatest interest during the proceedings. At other kraals where only one person was present this subject was interviewed. Of those who attended hospital clinics, the apparently healthy relatives and friends who accompanied the sick person were interviewed.

The rural men consisted of those who (a) had settled in the area as farmers and labourers, $(b)$ had returned from work in the city, $(c)$ had been unemployed in the city and had returned home, and (d) had returned to their rural homes for various reasons. It was not possible to obtain the exact age of the subjects, and it was estimated from the skin texture, hair characteristics, teeth, and local historical events during a subject's lifetime. It was decided to divide the groups into decades (on average it seems reasonable to suppose that the age of an individual was overestimated no more often than it was underestimated).

The two observers (both qualified nursing sisters) were from the racial group under study. There was a degree of between-observer agreement when measuring the blood pressures of the same patients. 
The observers were trained for four weeks to take accurate blood pressure readings as recommended by WHO (1962) ${ }^{7}$ and to interview subjects for possible factors predisposing to hypertension by means of a standardised questionnaire. Observer variation studies were done. One nurse concentrated on the urban study and the other nurse on the rural study. To win the confidence of the local population it was necessary to employ a nurse from that area. Spot checks were carried out in both studies. Febrile or physically or mentally distressed subjects were excluded.

Blood pressure was taken with a properly calibrated aneroid sphygmomanometer (cuff length $53 \mathrm{~cm}$, cuff width $14 \mathrm{~cm}$ ). The examination of and interview with each subject lasted for about one hour. During the interview three casual blood pressure readings were taken at minute intervals after the subject had been sitting and relaxed for at least five minutes. The pressure cuff was applied snugly to the bared unrestricted arm 2-3 cm above the antecubital fossa and supported at the level of the heart at an angle of $45^{\circ}$ away from the trunk. The cuff was rapidly inflated to $20-30 \mathrm{~mm} \mathrm{Hg}$ above the point at which the brachial artery was obliterated. Cuff pressure was allowed to fall at a rate of not more than 2-3 $\mathrm{mm} \mathrm{Hg}$ per pulse beat, and the point of first appearance of an audible pulse beat was recorded as the systolic pressure. The systolic and diastolic (4th phase muffling of the sounds and 5th phase disappearance of sounds) were recorded by the auscultatory method. The 4th phase was taken as the diastolic blood pressure. Hypertension was defined as a systolic pressure of $160 \mathrm{~mm} \mathrm{Hg}$ or more, or a diastolic pressure of $95 \mathrm{~mm} \mathrm{Hg}$ or more, or both. Readings were recorded to the nearest $5-10 \mathrm{~mm} \mathrm{Hg}$ gradation below the observed figures and were taken in both arms. The mean of the blood pressure between the two arms was taken if there were discrepancies. The pulse, height (without shoes), and body weight (with minimal clothing) were recorded. Correction for arm girth was not done because based on several studies it was found that arm girth did not distort the measurement of blood pressure as long as the cuff was long and wide. ${ }^{8}$

Urine analysis for albumin and sugar was done in all subjects. Subjects found to be hypertensive were referred either to the hospitals or their general practitioners. Hypertensive subjects in both studies were further examined to exclude a secondary cause for hypertension. The results were negative.

\section{Results}

The WHO definition of hypertension was used ${ }^{7}-$ namely, a systolic blood pressure equal to or greater

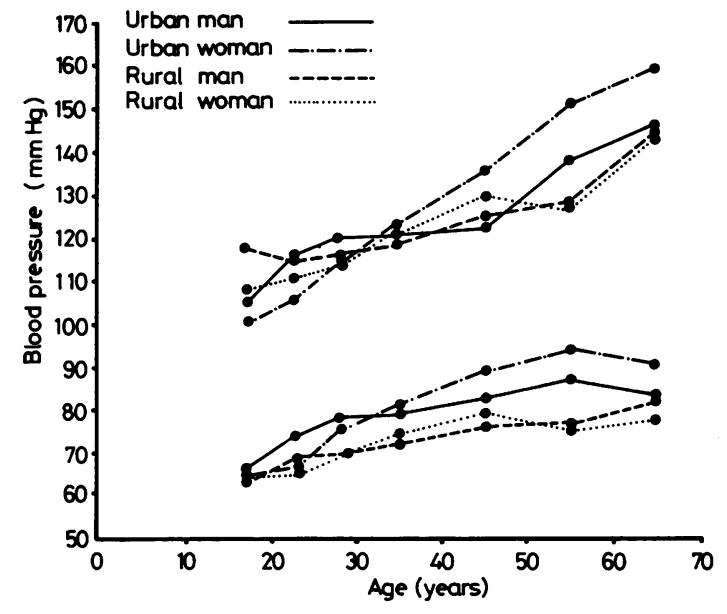

Mean systolic and diastolic blood pressure in urban and rural Zulu.

than $160 \mathrm{~mm} \mathrm{Hg}$ or a diastolic blood pressure equal to or greater than $95 \mathrm{~mm} \mathrm{Hg}$, or both, in a subject aged over 30 and under 65 . For subjects under 30 the values were taken at $150 \mathrm{~mm} \mathbf{~ g}$ or more systolic or $90 \mathrm{~mm} \mathrm{Hg}$ or more diastolic, or both; for subjects over 65 corresponding figures were $165 \mathrm{~mm} \mathrm{Hg}$ or more systolic or $95 \mathrm{~mm} \mathrm{Hg}$ or more diastolic, or both.

The mean systolic and diastolic blood pressure with standard deviation by age and sex for both studies are shown in tables 1 and 2 . Mean systolic and diastolic blood pressures of male and female urban and rural Zulus are compared in the figure. There was no statistical difference between blood pressure readings in the two arms, or between pulse rates in hypertensive or normotensive groups in either the urban or rural Zulu.

According to WHO criteria ${ }^{7}$ the prevalence of hypertension in urban Zulus was $25 \%$ (23\% men, $27 \%$ women) and in rural Zulus $10.5 \%$ (10\% men, $10.8 \%$ women). There was no difference in the prevalence of hypertension among urban men who resided in the hostels and the subeconomic houses. In the rural Zulu when the prevalence according to WHO criteria was corrected for age (the rural was corrected to the urban distribution) the prevalence rates were urban Zulu 25\% (23\% men, 27\% women) and rural Zulu 9.4\% (8.7\% men, 9.9\% women) (table $3)$. This difference was significant $(p<0.0005)$. When an overall criteria of a systolic blood pressure of $160 \mathrm{~mm} \mathrm{Hg}$ or more or $95 \mathrm{~mm} \mathrm{Hg}$ or more, or both, was used the prevalence of hypertension in the two groups were urban Zulus 21.4\% (18.7\% men, $23.9 \%$ women) and rural Zulus $10.7 \%$ (10\% men, $11.04 \%$ women). When these prevalence rates were 
Table 1 Diastolic blood pressure in the urban and rural Zulus

\begin{tabular}{|c|c|c|c|c|c|c|c|}
\hline \multicolumn{8}{|l|}{ Urban } \\
\hline Age & No & Mean & $S D$ & $<90$ & $90-94$ & $95-109$ & $>110$ \\
\hline $\begin{array}{l}\text { Men } \\
\leq 20 \\
21-25 \\
26-30 \\
31-40 \\
41-50 \\
51-60 \\
61-70\end{array}$ & $\begin{array}{r}52 \\
84 \\
65 \\
109 \\
80 \\
47 \\
22\end{array}$ & $\begin{array}{l}66.0 \\
74.8 \\
78.8 \\
79.2 \\
83.2 \\
87.4 \\
83.1\end{array}$ & $\begin{array}{l}15.3 \\
11.6 \\
14.0 \\
14.9 \\
18.0 \\
20.2 \\
17.8\end{array}$ & $\begin{array}{l}46 \\
77 \\
46 \\
81 \\
40 \\
19 \\
12\end{array}$ & $\begin{array}{r}3 \\
5 \\
10 \\
16 \\
13 \\
9 \\
5\end{array}$ & $\begin{array}{r}2 \\
2 \\
9 \\
10 \\
21 \\
10 \\
4\end{array}$ & $\begin{array}{l}1 \\
0 \\
0 \\
2 \\
6 \\
9 \\
1\end{array}$ \\
\hline $\begin{array}{l}\text { Total } \\
\text { \% }\end{array}$ & $\begin{array}{l}459 \\
100\end{array}$ & & & $\begin{array}{r}321 \\
70\end{array}$ & $\begin{array}{l}61 \\
13\end{array}$ & $\begin{array}{l}58 \\
13\end{array}$ & $\begin{array}{r}19 \\
4\end{array}$ \\
\hline $\begin{array}{l}\text { Women } \\
\leq 20 \\
21-25 \\
26-30 \\
31-40 \\
41-50 \\
51-60 \\
61-70\end{array}$ & $\begin{array}{r}93 \\
87 \\
82 \\
106 \\
83 \\
53 \\
31\end{array}$ & $\begin{array}{l}64.0 \\
66.8 \\
75.2 \\
81.2 \\
89.0 \\
94.4 \\
90.8\end{array}$ & $\begin{array}{l}12.4 \\
13.1 \\
16.0 \\
16.6 \\
18.7 \\
16.0 \\
14.1\end{array}$ & $\begin{array}{r}88 \\
79 \\
72 \\
69 \\
40 \\
12 \\
4\end{array}$ & $\begin{array}{r}4 \\
7 \\
5 \\
19 \\
12 \\
14 \\
10\end{array}$ & $\begin{array}{r}1 \\
1 \\
5 \\
13 \\
19 \\
11 \\
13\end{array}$ & $\begin{array}{c}0 \\
0 \\
0 \\
12 \\
16 \\
4\end{array}$ \\
\hline $\begin{array}{l}\text { Total } \\
\%\end{array}$ & $\begin{array}{l}535 \\
100\end{array}$ & & & $\begin{array}{r}364 \\
68\end{array}$ & $\begin{array}{l}71 \\
13\end{array}$ & $\begin{array}{l}63 \\
12\end{array}$ & $\begin{array}{r}37 \\
7\end{array}$ \\
\hline \multicolumn{8}{|l|}{ Rural } \\
\hline Age & No & Mean & $S D$ & $<90$ & $90-94$ & $95-109$ & $>110$ \\
\hline $\begin{array}{l}\text { Men } \\
\leq 20 \\
21-25 \\
26-30 \\
31-40 \\
41-50 \\
51-60 \\
61-70\end{array}$ & $\begin{array}{l}20 \\
26 \\
47 \\
81 \\
86 \\
46 \\
21\end{array}$ & $\begin{array}{l}63.5 \\
68.0 \\
69.2 \\
72.0 \\
76.9 \\
76.8 \\
83.2\end{array}$ & $\begin{array}{l}13.0 \\
11.1 \\
10.3 \\
10.3 \\
17.3 \\
14.9 \\
17.3\end{array}$ & $\begin{array}{l}19 \\
24 \\
44 \\
75 \\
66 \\
34 \\
15\end{array}$ & $\begin{array}{r}1 \\
1 \\
2 \\
5 \\
10 \\
5 \\
1\end{array}$ & $\begin{array}{l}0 \\
1 \\
1 \\
1 \\
6 \\
7 \\
3\end{array}$ & $\begin{array}{l}0 \\
0 \\
0 \\
0 \\
4 \\
0 \\
2\end{array}$ \\
\hline $\begin{array}{l}\text { Total } \\
\%\end{array}$ & $\begin{array}{l}327 \\
100\end{array}$ & & & $\begin{array}{r}277 \\
85\end{array}$ & $\begin{array}{r}25 \\
7\end{array}$ & $\begin{array}{r}19 \\
6\end{array}$ & $\begin{array}{l}6 \\
2\end{array}$ \\
\hline $\begin{array}{l}\text { Women } \\
\leq 20 \\
21-25 \\
26-30 \\
31-40 \\
41-50 \\
51-60 \\
61-70\end{array}$ & $\begin{array}{r}49 \\
112 \\
114 \\
163 \\
132 \\
72 \\
18\end{array}$ & $\begin{array}{l}64.3 \\
66.2 \\
69.5 \\
74.3 \\
79.3 \\
76.1 \\
78.5\end{array}$ & $\begin{array}{l}10.6 \\
11.2 \\
12.6 \\
13.5 \\
14.8 \\
14.3 \\
17.5\end{array}$ & $\begin{array}{r}49 \\
106 \\
107 \\
135 \\
93 \\
57 \\
13\end{array}$ & $\begin{array}{r}0 \\
3 \\
2 \\
12 \\
17 \\
9 \\
2\end{array}$ & $\begin{array}{r}0 \\
3 \\
3 \\
14 \\
17 \\
3 \\
1\end{array}$ & $\begin{array}{l}0 \\
0 \\
2 \\
2 \\
5 \\
3 \\
2\end{array}$ \\
\hline $\begin{array}{l}\text { Total } \\
\times\end{array}$ & $\begin{array}{l}660 \\
100\end{array}$ & & & $\begin{array}{r}560 \\
85\end{array}$ & $\begin{array}{r}45 \\
7\end{array}$ & $\begin{array}{r}41 \\
6\end{array}$ & $\begin{array}{r}14 \\
2\end{array}$ \\
\hline
\end{tabular}

corrected for age the rural Zulu prevalence rates were $9.2 \%(7.9 \%$ men, $10.3 \%$ women). If a hypertensive patient was known to be taking hypotensive drugs the original blood pressure was obtained from the doctor who recorded it. The mean number of years for residence of Zulus in Durban was significantly greater in both male and female hypertensive subjects than in normotensive subjects (hypertensive men 24.5 years compared with normotensive men 15.9 years and hypertensive women 24.6 years compared with normotensive women 16.9 years. The level of significance for men was $p<0.05$ and for women $p<0.001$ ).
Eight per cent of the urban Zulu and 2.9\% of the rural Zulu reported a family history of hypertension among parents or siblings.

Of the identified hypertensive subjects, $8 \%$ of the urban hypertensive subjects were being treated and $27 \%$ of the rural (table 4 ).

The results of the urine analysis were as follows:

Urban study-There was no difference in the prevalence of proteinuria between the normotensive and hypertensive subjects. The prevalence of proteinuria was under $1 \%$.

Rural study-The prevalence of proteinuria in the rural Zulus was $5.5 \%$ with no difference between 
Table 2 Systolic blood pressure in the urban and rural Zulus

\begin{tabular}{|c|c|c|c|c|c|c|c|c|}
\hline \multicolumn{9}{|l|}{ Urban } \\
\hline Age & No & Mean & $S D$ & $<140$ & $140-149$ & $150-159$ & $160-169$ & $>170$ \\
\hline $\begin{array}{l}\text { Men } \\
\leq 20 \\
21-25 \\
26-30 \\
31-40 \\
41-50 \\
51-60 \\
61-70\end{array}$ & $\begin{array}{r}52 \\
84 \\
65 \\
109 \\
80 \\
47 \\
22\end{array}$ & $\begin{array}{l}105.2 \\
116.2 \\
120.0 \\
121.6 \\
123.6 \\
138.4 \\
146.1\end{array}$ & $\begin{array}{l}16 \cdot 5 \\
14 \cdot 8 \\
17 \cdot 3 \\
21 \cdot 2 \\
22 \cdot 9 \\
35 \cdot 8 \\
27 \cdot 0\end{array}$ & $\begin{array}{r}49 \\
78 \\
58 \\
88 \\
47 \\
23 \\
6\end{array}$ & $\begin{array}{r}2 \\
5 \\
7 \\
10 \\
16 \\
7 \\
6\end{array}$ & $\begin{array}{l}0 \\
1 \\
0 \\
2 \\
6 \\
6 \\
2\end{array}$ & $\begin{array}{l}1 \\
0 \\
0 \\
3 \\
5 \\
4 \\
3\end{array}$ & $\begin{array}{l}0 \\
0 \\
0 \\
6 \\
6 \\
7 \\
5\end{array}$ \\
\hline $\begin{array}{l}\text { Total } \\
\%\end{array}$ & $\begin{array}{l}459 \\
100\end{array}$ & & & $\begin{array}{r}349 \\
76\end{array}$ & $\begin{array}{l}53 \\
12\end{array}$ & $\begin{array}{r}17 \\
4\end{array}$ & $\begin{array}{r}16 \\
3\end{array}$ & $\begin{array}{r}24 \\
5\end{array}$ \\
\hline $\begin{array}{l}\text { Women } \\
\leq 20 \\
21-25 \\
26-30 \\
31-40 \\
41-50 \\
51-60 \\
61-70\end{array}$ & $\begin{array}{r}93 \\
87 \\
82 \\
106 \\
83 \\
53 \\
31\end{array}$ & $\begin{array}{l}101.2 \\
106.5 \\
115.2 \\
124.0 \\
136.4 \\
151.1 \\
160.0\end{array}$ & $\begin{array}{l}12.8 \\
13.2 \\
21.1 \\
24.7 \\
29.5 \\
30.0 \\
37.6\end{array}$ & $\begin{array}{r}88 \\
81 \\
76 \\
75 \\
36 \\
20 \\
4\end{array}$ & $\begin{array}{r}3 \\
5 \\
5 \\
10 \\
19 \\
7 \\
6\end{array}$ & $\begin{array}{r}2 \\
0 \\
0 \\
9 \\
10 \\
7 \\
4\end{array}$ & $\begin{array}{l}0 \\
1 \\
1 \\
5 \\
4 \\
9 \\
5\end{array}$ & $\begin{array}{r}0 \\
0 \\
0 \\
7 \\
14 \\
10 \\
12\end{array}$ \\
\hline $\begin{array}{l}\text { Total } \\
\%\end{array}$ & $\begin{array}{l}535 \\
100\end{array}$ & & & $\begin{array}{r}380 \\
71\end{array}$ & $\begin{array}{l}55 \\
10\end{array}$ & $\begin{array}{r}32 \\
6\end{array}$ & $\begin{array}{r}25 \\
5\end{array}$ & $\begin{array}{r}43 \\
8\end{array}$ \\
\hline Rural & & & & & & & & \\
\hline Age & No & Mean & $S D$ & $<140$ & $140-149$ & $150-159$ & $160-169$ & $\geq 170$ \\
\hline $\begin{array}{l}\text { Men } \\
\leq 20 \\
21-25 \\
26-30 \\
31-40 \\
41-50 \\
51-60 \\
61-70\end{array}$ & $\begin{array}{l}20 \\
26 \\
47 \\
80 \\
86 \\
46 \\
21\end{array}$ & $\begin{array}{l}118.1 \\
115.5 \\
116.9 \\
118.5 \\
125.7 \\
128.3 \\
146.2\end{array}$ & $\begin{array}{l}17.8 \\
12.9 \\
12.0 \\
15.2 \\
25.6 \\
22.1 \\
29.7\end{array}$ & $\begin{array}{r}17 \\
25 \\
44 \\
71 \\
64 \\
29 \\
8\end{array}$ & $\begin{array}{r}0 \\
0 \\
3 \\
5 \\
10 \\
9 \\
5\end{array}$ & $\begin{array}{l}3 \\
1 \\
0 \\
3 \\
5 \\
3 \\
0\end{array}$ & $\begin{array}{l}0 \\
0 \\
0 \\
1 \\
4 \\
3 \\
2\end{array}$ & $\begin{array}{l}0 \\
0 \\
0 \\
0 \\
3 \\
2 \\
6\end{array}$ \\
\hline $\begin{array}{l}\text { Total } \\
\%\end{array}$ & $\begin{array}{l}326 \\
100\end{array}$ & & & $\begin{array}{r}258 \\
79\end{array}$ & $\begin{array}{l}32 \\
10\end{array}$ & $\begin{array}{r}15 \\
5\end{array}$ & $\begin{array}{r}10 \\
3\end{array}$ & $\begin{array}{r}11 \\
3\end{array}$ \\
\hline $\begin{array}{l}\text { Women } \\
\leq 20 \\
21-25 \\
26-30 \\
31-40 \\
41-50 \\
51-60 \\
61-70\end{array}$ & $\begin{array}{r}50 \\
112 \\
114 \\
163 \\
132 \\
73 \\
18\end{array}$ & $\begin{array}{l}108.0 \\
111.7 \\
114.3 \\
121.9 \\
130.2 \\
127.8 \\
144.2\end{array}$ & $\begin{array}{l}20.0 \\
12.2 \\
15.7 \\
19.3 \\
24.5 \\
22.8 \\
41.1\end{array}$ & $\begin{array}{r}50 \\
109 \\
105 \\
131 \\
86 \\
47 \\
11\end{array}$ & $\begin{array}{r}0 \\
2 \\
6 \\
17 \\
18 \\
13 \\
1\end{array}$ & $\begin{array}{l}0 \\
1 \\
1 \\
6 \\
9 \\
9 \\
5 \\
1\end{array}$ & $\begin{array}{l}0 \\
0 \\
1 \\
5 \\
6 \\
4 \\
1\end{array}$ & $\begin{array}{r}0 \\
0 \\
1 \\
4 \\
13 \\
4 \\
4\end{array}$ \\
\hline $\begin{array}{l}\text { Total } \\
\text { \% }\end{array}$ & $\begin{array}{l}662 \\
100\end{array}$ & & & $\begin{array}{r}539 \\
81\end{array}$ & $\begin{array}{r}57 \\
9\end{array}$ & $\begin{array}{r}23 \\
3\end{array}$ & $\begin{array}{r}17 \\
3\end{array}$ & $\begin{array}{r}26 \\
4\end{array}$ \\
\hline
\end{tabular}

normotensive and hypertensive subjects. The relatively high prevalence of proteinuria in our study may be partly due to schistosomiasis, which is known to be endemic in Natal. Since only $0.8 \%$ of those with proteinuria had hypertension such hypertension as was found in the rural areas was probably predominantly primary in origin. There was no association between glycosuria and hypertension in the urban and rural Zulu.

\section{Discussion}

This study was done to compare and contrast the prevalence of hypertension in the urban and rural Zulu. The age-corrected prevalance of hypertension was found to be $21.4 \%$ (18.7\% men, $23.9 \%$ women) in rural Zulus $9.2 \%(7.9 \%$ men, $10.3 \%$ women) based on the criteria of a systolic blood pressure of $160 \mathrm{~mm} \mathrm{Hg}$ or more, or a diastolic blood pressure of $95 \mathrm{~mm} \mathrm{Hg}$ or more, or both, for all age groups. The age-corrected prevalence rates for hypertension using the WHO criteria in the urban Zulu was $25 \%$ (23\% men, 27\% women) and in the rural Zulu 9.4\% (8.7\% men and $10 \%$ women). Thus there was a pronounced difference between the prevalence of hypertension in the urban and rural Zulu $(p<0.0005)$. There was an earlier onset of hypertension in the urban and rural Zulu women. The prevalence of hypertension in the rural Zulus was higher than that found in other rural studies in 
Table 3 Age-connected prevalence in urban and rural Zulus ${ }^{7}$

\begin{tabular}{|c|c|c|c|c|}
\hline \multicolumn{5}{|l|}{ Urban } \\
\hline Age & $\begin{array}{l}\text { No of } \\
\text { hypertensives }\end{array}$ & $\begin{array}{l}\text { Column } \\
\text { (\%) }\end{array}$ & Total & $\begin{array}{l}\text { Row } \\
\text { (\%) }\end{array}$ \\
\hline $\begin{array}{l}\text { Men } \\
520 \\
21-25 \\
26-30 \\
31-40 \\
41-50 \\
51-60 \\
61-70\end{array}$ & $\begin{array}{r}5 \\
15 \\
17 \\
18 \\
20 \\
21 \\
8\end{array}$ & $\begin{array}{r}5 \\
15 \\
16 \\
17 \\
19 \\
20 \\
8\end{array}$ & $\begin{array}{r}52 \\
84 \\
65 \\
109 \\
80 \\
47 \\
22\end{array}$ & $\begin{array}{l}10 \\
18 \\
26 \\
17 \\
25 \\
45 \\
36\end{array}$ \\
\hline Total & 104 & 100 & 459 & 23 \\
\hline $\begin{array}{l}\text { Women } \\
\leq \\
21-25 \\
26-30 \\
31-40 \\
41-50 \\
51-60 \\
61-70\end{array}$ & $\begin{array}{r}7 \\
10 \\
21 \\
26 \\
34 \\
29 \\
20\end{array}$ & $\begin{array}{r}5 \\
7 \\
14 \\
18 \\
23 \\
20 \\
13\end{array}$ & $\begin{array}{r}93 \\
87 \\
82 \\
106 \\
83 \\
53 \\
31\end{array}$ & $\begin{array}{r}8 \\
11 \\
26 \\
25 \\
41 \\
55 \\
65\end{array}$ \\
\hline Total & 147 & 100 & 535 & 27 \\
\hline \multicolumn{5}{|l|}{ Rural } \\
\hline Age & $\begin{array}{l}\text { No of } \\
\text { hypertensives }\end{array}$ & $\begin{array}{l}\text { No of } \\
\text { hypertensives } \\
\text { age-corrected }\end{array}$ & $\begin{array}{l}\text { Columen } \\
\text { (\%) }\end{array}$ & $\begin{array}{l}\text { Row } \\
\text { (\%) }\end{array}$ \\
\hline $\begin{array}{l}\text { Men } \\
\leq 20 \\
21-25 \\
26-30 \\
31-40 \\
41-50 \\
51-60 \\
61-70\end{array}$ & $\begin{array}{r}1 \\
2 \\
3 \\
1 \\
12 \\
8 \\
6\end{array}$ & $\begin{array}{r}3 \\
7 \\
4 \\
1 \\
11 \\
8 \\
6\end{array}$ & $\begin{array}{r}7 \\
16 \\
10 \\
3 \\
28 \\
20 \\
16\end{array}$ & $\begin{array}{r}5 \\
8 \\
6 \\
1 \\
14 \\
17 \\
29\end{array}$ \\
\hline Total & 33 & 40 & 100 & 9 \\
\hline $\begin{array}{l}\text { Women } \\
520 \\
21-25 \\
26-30 \\
31-40 \\
41-50 \\
51-60 \\
61-70\end{array}$ & $\begin{array}{r}1 \\
8 \\
8 \\
17 \\
26 \\
8 \\
4\end{array}$ & $\begin{array}{r}2 \\
6 \\
7 \\
11 \\
16 \\
5 \\
7\end{array}$ & $\begin{array}{r}3 \\
12 \\
11 \\
20 \\
30 \\
11 \\
13\end{array}$ & $\begin{array}{r}2 \\
7 \\
7 \\
10 \\
19 \\
11 \\
22\end{array}$ \\
\hline Total & 72 & 53 & 100 & 10 \\
\hline
\end{tabular}

Table 4 Therapeutic situation in the urban and rural Zulus known, or found to be suffering from, hypertension

\begin{tabular}{|c|c|c|c|c|}
\hline \multirow{2}{*}{$\begin{array}{l}\text { Hypericusive } \\
\text { treatmens }\end{array}$} & \multicolumn{2}{|c|}{ Urbar } & \multicolumn{2}{|c|}{ Rural } \\
\hline & No & $\%$ & No & $\%$ \\
\hline $\begin{array}{l}\text { Treatment } \\
\text { Treatment }\end{array}$ & 21 & 8 & 28 & 27 \\
\hline $\begin{array}{l}\text { discontinued } \\
\text { No treatment }\end{array}$ & $\begin{array}{r}14 \\
216\end{array}$ & $\begin{array}{r}6 \\
86\end{array}$ & $\begin{array}{r}3 \\
74\end{array}$ & $\begin{array}{r}3 \\
70\end{array}$ \\
\hline Total & 251 & 100 & 105 & 100 \\
\hline
\end{tabular}

Africa- $4.1 \%$ in Ghana, ${ }^{9} 5.9 \%$ in Nigeria, ${ }^{10}$ and $7 \%$ in Lesotho. ${ }^{11}$ The blood pressure of the Bushmen in the Kalahari Desert has been shown not to rise with age. ${ }^{12}$ Similar urban/rural differences in blood pressure have been found among Zulus, ${ }^{13}$ among the Xhosas of South Africa, ${ }^{14}$ and in the general population of Haryana (India). ${ }^{15}$

Mean systolic and diastolic blood pressures were higher in both urban and rural women (figure). The distribution of systolic blood presssure in the rural Zulu did not show a smooth rise with age (tables 1 and 2 and figure). The mean systolic and diastolic blood prẹssures rose more definitely with age (figure).

Several factors may contribute to the lower prevalence of high blood pressure in the rural Zulu. A family history of hypertension was obtained in only $2.9 \%$ of the sample, suggesting that environmental rather than genetic factors cause hypertension. Increased physical activity and more traditional dietary patterns in the rural Zulu may favourably affect blood pressure. Rural Zulus are less obese than urban Zulus, and both urban and rural Zulu women are more obese compared with the Zulu men. ${ }^{16}$ There was a relation between sociable variables observed to be stressful and hypertension. Unlike the rural Zulu the urban Zulu is exposed to a different life style, acculturation, detribalisation, and the practice of political ideologies, which could explain the difference in the prevalence of hypertension between the urban and rural Zulu. ${ }^{16}$

In contrast to the urban Zulu, which showed that $90 \%$ of the hypertensive subjects were undiagnosed, undetected, or inadequately treated, $27 \%$ of the rural Zulus with hypertension were being treated. This suggests that compliance is better in a community based around a rural hospital with outlying clinics.

In conclusion, hypertension in the urban black of South Africa behaves in an explosive manner, resulting in cerebral haemorrhage, uraemia, or cardiac failure. ${ }^{4}$ The high prevalence of hypertension in the urban Zulu in our study makes it imperative that preventive and therapeutic programmes should be started to control the complications of hypertension. We have come to conclusions similar to those of Pobee et al ${ }^{\ominus}$ in rural Ghanaians and think that hypertension in rural Zulus is not a major health problem. If scarce rural health resources are to be allocated to treatment attention should be given to eradicating infectious diseases such as tuberculosis, schistosomiasis, and malnutrition in developing countries.

This study was supported by the Medical Research Council of South Africa. We wish to thank Mrs J Mpontshane and M N Nkomo for doing the study. 
Request for reprints: Professor Y K Seedat, Department of Medicine, University of Natal, P O Box 17039, Congella 4013, Durban, Republic of South Africa.

\section{References}

${ }^{1}$ Fraser BN. Manifestations and aetiology of hypertension in the Coloured and Bantu. Br Med J 1959; i: 761-4.

${ }^{2}$ Ordman B. A review of the incidence of hypertension in the non-European races. Clinical Proceedings 1948; 7: 183-210.

${ }^{3}$ Schrire V. The racial incidence of heart disease at Groote Schuur Hospital, Cape Town. Part II Hypertension and valvular disease of the heart. Am Heart J 1958; 56: 742-60.

${ }^{4}$ Seedat YK, Reddy J. The clinical pattern of hypertension in the South African black population: a study of 1000 patients. Afr J Med Med Sci 1976; 5: 1-7.

${ }^{5}$ Seftel HC. Medicine and society in South Africa-some plain thinking. Johannesburg: Witwatersrand University Press, 1973: 14.

${ }^{6}$ Department of Statistics. Population of South A frica 1904-1970. Pretoria: Government House, 1976. (Report No 02-05-12.)
${ }^{7}$ World Health Organisation. Arterial hypertension and ischaemic heart disease: preventive aspects. Geneva: WHO, 1962. (Technical Report Series No 231.)

${ }^{8}$ Epstein FH. Hypertension risk factors: a preventive point of view. In: Gross F, Strasser T, eds. Mild hypertension. Natural history and management. Tunbridge Wells: Pitman Medical, 1979: 127-38.

${ }^{9}$ Pobee JOM, Larbi EB, Belcher DW, et al. Blood pressure distribution in a rural Ghanian population. Trans $R$ Soc Trop Med Hyg 1977; 71: 66-72.

${ }^{10} \mathrm{Oviasu}$ VO. Arterial blood pressures and hypertension in a rural Nigerian community. Afr J Med Med Sci 1978; 7: 137-43.

${ }^{11}$ Mokhobo KP. Arterial hypertension in rural societies. $E$ Afr Med J 1976; 52: 440-4.

${ }^{12}$ Kaminer B, Lutz WPW. Blood pressure in Bushmen of the Kalahari Desert. Circulation 1960; 22: 289-95.

${ }^{13}$ Gampel B, Slome C, Scotch N, Abramson JH. Urbanisation and hypertension among Zulu adults. $J$ Chronic Dis 1962; 15: 67-70.

${ }^{14}$ Sever PS, Gordon D, Peart WS, Beighton P. Blood pressure and its correlates in urban and tribal Africa. Lancet 1980; ii: $60-4$.

${ }^{15}$ Gupta SP, Suriach SB, Gupta MS. Hypertension and blood pressure trends in the general population of Haryana (based on total community surveys). J Assoc Physicians 1979; 27: 119-26.

${ }^{16}$ Seedat YK, Seedat MA, Hackland DBT. Biosocial factors and hypertension in urban and rural Zulu. S Afr Med J 1982; 61: 999-1002. 